\title{
A Contrastive Study of Word Sequence of English and Chinese Nominal Groups: A Systemic Functional Approach
}

\author{
Guichao Zhang ${ }^{1} \&$ Manliang $\mathrm{Li}^{1}$ \\ ${ }^{1}$ School of Foreign Languages, Shanghai Jiaotong University, Shanghai, China \\ ${ }^{1}$ Foreign Languages College, Inner Mongolia University, Hohhot, China \\ Correspondence: Manliang Li, Foreign Languages College, Inner Mongolia University, Hohhot 010021, Inner \\ Mongolia Autonomous Region, China. Tel: 86-0471-499-6235. E-mail: flclm195@imu.edu.cn
}

\author{
Received: July 16, 2017 Accepted: August 21, $2017 \quad$ Online Published: August 30, 2017 \\ doi:10.5539/ells.v7n3p53 URL: http://doi.org/10.5539/ells.v7n3p53
}

\begin{abstract}
Nominal group is always a heating study object for linguists. There are many scholars who have shed light on this field. However, among the current studies, most of them are just confined into the language of English. The contrastive study of nominal groups in English and Chinese, especially the study of the word sequence of modifiers, is rarely to be found. This paper, adopting a systemic functional approach, mainly conducted under the guidance of Halliday's interpretation of nominal groups from the experiential point of view, attempts to make a contrastive study of the similarities and differences between Chinese and English nominal groups with respect to the word sequence of their modifiers. On the one hand, this paper is a tentative study of word sequence of the modifiers both in Chinese nominal groups and English nominal groups, aiming to make a general description of them; on the other hand, through the contrast, we are trying to enable the readers to have a better understanding of the mechanism of the modifiers in nominal groups in both languages.
\end{abstract}

Keywords: contrastive study, modifier, nominal group, Systemic Functional Grammar, word sequence

\section{Introduction}

Quirk et al. (1985, p. 1238) held that "just as the sentence may be indefinitely complex, so may the noun phrase. This must be so, since sentences themselves can be reshaped so as to come within noun-phrase structure." Therefore, the study of nominal group (namely, noun phrase in Quirk's sense) is always attached great significance. There are many scholars who have shed light on this field already, such as Quirk et al. (1985), Halliday (1994/2000) and Fawcett (2008) and so on. They all make an elaborative analysis on nominal groups.

However, these studies are mainly concentrated on the discussion of English nominal groups, and few studies have been conducted in Chinese nominal groups, not to mention the contrastive study between the nominal groups in both languages.

Therefore, this paper aims to go deeper into the nominal groups, specifically the word sequence of nominal groups in both languages, from a systemic functional perspective. The analysis, mainly conducted by Halliday's experiential interpretation of nominal groups, manifests that this point of view can definitely provide a better contrast of the similarities and differences lying in the nominal groups in both languages, especially in the aspect of the word sequence in modifiers. The study is of great value and undoubtedly provides a brand-new understanding of nominal groups in both languages.

\section{Literature Review}

Unlike Chinese, English is a highly nominalized language, and thus lexical meaning is largely carried in nominal groups. Thus, the study of nominal groups is always of great value.

For the traditional grammar linguists (e.g., Quirk et al., 1985), a nominal group refers to the grammatical unit that lies between a word and a sentence. The term "phrase" is preferable to them, such as, noun phrase, verb phrase, prepositional phrase, which shows little difference from the meaning of "group". Quirk et al. (1985, pp. 1238-1352) have made an exclusive description of noun phrase, especially the relative sequence of noun phrases. Quirk et al. (1985, p. 1338) pointed out that "in order to describe the rules for the relative order of premodifiers, it will be helpful to divide the territory between DET (the determinative) and HEAD (the head) into four 
premodification zones." They are, precentral, central, postcentral, and prehead position. Then they made a thorough discussion in terms of their respective characteristics and classifications. Their contribution has laid a solid foundation to the following studies. However, the illustration centering on the noun phrase is only restricted within the language of English. Furthermore, their study of noun phrase belongs to descriptive analysis rather than contrastive studies between two languages.

For the Systemic Functional Grammar (SFG hereafter) linguists (Halliday \& Matthiessen, 2004), however, the term "group" and "phrase" are totally identified as two different conceptions. In SFG, a nominal group refers to a group of words which represents or describes an entity, for example the elegant old lady who was dressed in white. Grammatically, the wording the elegant old lady who was dressed in white can be understood as a nominal group, which functions as a description of someone (an entity).

As is mentioned above, a nominal group is broadly considered as the synonym with noun phrase in other grammatical theories. However, there is one prominent difference between the functional notion of a nominal group and the formal notion of a noun phrase that must be taken into consideration. Halliday and some of his followers make a theoretical distinction between the terms group and phrase. Halliday \& Matthiessen (2004, p. 311 ) argued that "a phrase is different from a group in that, whereas a group is an expansion of a word, a phrase is a contraction of a clause." The nominal group is a structure which contains not only nouns, but also some other items that are associated with the Thing under description, such as, adjectives, numerals and determiners, etc. Accordingly, in terms of classification of this structure, they identify the functions as Deictic, Numerative, Epithet, Classifier and Thing. They then made a discussion of each element respectively. Admittedly, Halliday \& Matthiessen (2004) have made a thorough illustration of nominal group whereas the discussion is also confined into the language of English.

In the meantime, there are many other scholars who also make some attempts in this aspect with the hope of exploring some new methods to study the nominal groups. Li (2009) discusses the similarities and the differences of the two models, the Sydney Grammar and the Cardiff Grammar, in depicting the nominal group in English and all these similarities and differences can demonstrate that the two models have the same theoretical basis and have their own characteristics as well. He further argues that the combination of the two models in describing the English nominal group will be of great value in practice.

Zhang (2009) attempts to explore the strengths and weaknesses of the Cardiff Grammar's description by comparing different descriptions as to "head" in the nominal group, in traditional grammar, the Sydney Grammar and the Cardiff Grammar.

As for the study of Chinese nominal groups, due to its complexity, it is not as abundant as the study in English. There are few scholars that set foot in the field of the word sequence of Chinese nominal groups. In current studies, the most representative ones should be He's and Peng's study (He \& Hong, 2014; Peng, 2009).

He \& Hong (2014) make a descriptive study of three Chinese phenomena pertaining to de, including modifying nominal phrase, appositive nominal phrase and de-phrase, within the framework of the Cardiff Grammar, so that the different semantic and syntactic functions of $d e$ in these phenomena could be revealed. In their study, the authors first describe the three phenomena as the same linguistic unit-nominal group, and then show that de plays an independent role in the meaning realized by the nominal group, and that de expounds the modifier trigger, selector, genitive, reifier trigger, qualifier trigger or head trigger element in the functional structure of the nominal group. The study better solves some divergences of meanings in the language of Chinese.

Peng's study (2009) makes attempts to account for the deictic elements in Chinese nominal groups, with particular reference to their systems and order. The chief points include: (i) deictic pro-form system, (ii) word order of specific and non-specific deictics, (iii) order of multiple non-specific deictics and non-specific and deictic numerative elements, and (iv) positions of non-specific deictic elements. It finally provides an overall framework for the possible configurations of the positions and functions of all the deictic elements in question. The discussion will benefit those who are learning as well as studying the relevant issues. Apparently, the studies are far from being adequate.

Admittedly, the studies of nominal groups mentioned above have covered many aspects and these studies have provided us with a better understanding of the nominal groups. However, the inadequacies are also rather apparent. These studies only focus on the language of English. Few studies have been conducted on the contrastive study, especially from the perspective of SFG.

First, there are relatively a few studies focusing on the analysis of Chinese nominal groups from a systemic functional point of view despite the rapid development of SFG theory. Most importantly, the word sequence of 
modifiers in nominal groups between English and Chinese has never been addressed from the perspective of SFG. When Quirk et al. (1985) discussed the relative sequence of premodifiers, they (Quirk et al., 1985, p. 1337) pointed out that "when a head has more than one premodifier, there arises the question of relative order; ...The problem becomes even more acute with longer strings of premodifiers." Therefore, nominal groups are worth our further study. Based on the points above, this paper aims to carry out its study from a systemic functional perspective, attempting to provide a brand-new angle towards the contrastive study of the similarities and differences of nominal groups with respect to their word sequence in both languages.

\section{Theoretical Framework}

Since SFG was put forward, there have been large quantities of studies on it in linguistic areas in China. SFG has been applied into many other fields, which has been proved to be a very powerful and practical tool for the analysis. Its significance is obvious.

\subsection{Components of a Nominal Group}

According to Halliday (1994/2000, p. 310), groups can be classified into nominal groups, verbal groups, and adverbial groups and some other groups, like preposition groups and conjunction groups, in which the explanation of nominal group can be a very important part.

A nominal group includes many other components except for a noun. Usually, they are adjectives, numerals and determiners. They perform different functions in a nominal group. Halliday (1994/2000, p. 312) identifies their functions as Deictic, Numerative, Epithet, Classifier and Thing (the noun). The word classes which typically realize these functions are listed in Table 1 below:

Table 1. Functions of word classes in a nominal group

\begin{tabular}{|c|c|c|c|c|c|}
\hline Deictic 1 & Deictic 2 & Numerative & Epithet & Classifier & Thing \\
\hline determiner & adjective & numeral & adjective & noun or adjective & noun \\
\hline
\end{tabular}

Within a nominal group, the noun is referred to as the head; the items preceding the head are called the Premodifier, and the items after it the Qualifier. Consider the following clause:

Look at those two splendid old electric trains with pantographs!

Halliday \& Matthiessen (2004, p. 311)

This clause consists of one long nominal group, those two splendid old electric trains with pantographs. We can interpret the first part, namely, the Premodifier, of this nominal group structurally as Table 2. "This is an experiential structure which, taken as a whole, has the function of specifying (i) a class of things, namely trains, and (ii) some category of membership within this class" (ibid, p. 312).

Table 2. Interpretation of the Premodifier

\begin{tabular}{llllll}
\hline Deictic & Numerative & Epithet & Epithet & Classifier & Thing \\
\hline determiner & numeral & adjective & adjective & adjective & noun \\
those & two & splendid & old & electric & trains \\
\hline
\end{tabular}

This group contains the noun trains preceded and followed by various other items all of them in some way used for describing the train. "These occur in a certain sequence; and the sequence is largely fixed, although some variation is possible" (ibid., p. 312). Therefore, the word sequence here can be taken as a general standard to measure the feasibility of a nominal group. For example, if we change the sequence of certain items randomly, like,

\section{*two splendid those old electric trains}

Apparently, the nominal group gets invalid and unperceivable. That is to say, when forming a correct nominal group, we have to abide by certain sequence, which is, in most cases, fixed and cannot be changed randomly.

What is the element that follows the Thing with pantographs? This is also part of the nominal group, which appears behind the Thing. It is called, just as is mentioned above, Qualifier. The elements that appear in front of the Thing, are usually are words, but what appears behind the Thing is either a phrase or a clause (ibid., p. 323). For example, 


\section{an elegant lady in white}

an expensive bike that Mike bought last year

However, Halliday \& Matthiessen (2004) argued that the Qualifier should not be included within a nominal group in a strict sense, for they $(2004$, p. 323) pointed out that "with only rare exceptions, all Qualifiers are rank-shifted. What this means is that position following the Thing is reserved for those items which, in their own structure, are of a rank higher than or at least equivalent to that of the nominal group; on these grounds, therefore, they would not be expected to be constituents of a nominal group. Such items are said to be "rank-shifted", by contrast with ranking ones which function prototypically as constituents of the higher unit." Therefore, when analyzing the nominal group, especially the word sequence of a nominal group, we will draw more concentration on the Premodifiers rather than the Qualifiers. For another reason, there are few Qualifiers used in Chinese nominal groups.

The interpretation of nominal group mentioned above is conducted from the experiential point of view. However, Halliday \& Matthiessen (2004, pp. 309-310) held that "at the same time, in interpreting group structure we have to split the ideational component into two: experiential and logical. So far what we have been describing under the ideational heading has been meaning as organization of experience; but there is also a logical aspect to it-language as the expression of certain very general logical relations..." The logical component is used to define complex units, for example the clause complex. Therefore, it is not very suitable for the discussion of the word sequence of the modifiers in nominal groups.

This paper, carried out under the guidance of SFG, attempts to reveal the similarities and differences of the word sequence of nominal groups in English and Chinese.

\subsection{Mechanism of the Premodifiers}

According to Halliday and Matthiessen (2004, p. 312), the word sequence of Premodifier is largely fixed and cannot be changed randomly. They have to abide by certain principle, namely, the here-and-now principle. Just as they said, "so there is a progression in the nominal group from the kind of element that has the greatest specifying potential to that which has the least; and this is the principle of ordering that we have already recognized in the clause" (ibid., p. 322). For example, in the nominal group those six beautiful red Gala apples, the first word of the nominal group those is a Deictic, as opposed to these apples, indicates "the apples over there, not close to me". The Epithet implies some quality of the Thing: both beautiful and red function as Epithet: the former is an interpersonal Epithet, since it is an expression of the speaker's subjective attitude towards the apples while red is an experiential Epithet, in that it describes an objective quality that we can all experience; Gala is a Classifier, which indicates a particular subclass of the Thing; six is a Numerative, which describes not the quality of the Thing but its quantity.

It can be seen that there is a progression from the start of the nominal group till the end, in which the items will be narrowed down from the greatest specifying potential to the successively less identifying potential and thus they are getting increasingly permanent as attributes of the Thing. As Halliday \& Matthiessen (2004, p. 323) thought, "the more permanent the attribute of a thing, the less likely it is to identify it in a particular context." Therefore, in this nominal group, the Deictic those comes first, for it bears the greatest specifying potential. Then, it is followed by the Numerative six, since the number of apples can be changeable, namely, not that permanent. Next come the interpersonal Epithet beautiful and experiential Epithet red, since they indicate the speaker's viewpoint, thus closer to the here-and-now principle. Gala, the Classifier, is more permanent than any other items, and therefore is closest to the Thing. The most permanent item, absolutely, is the Thing itself. This pattern from the temporal specification to permanent attribute explains why the items are ordered as they are in a nominal group.

The discussion section will take this principle as a standard to make a contrastive study of the similarities and differences of the word sequence in a nominal group.

\section{Research Methodology}

The research methodology of this paper should be clarified here. According to Widdowson (1996/2000, pp. 72-75), "there are, broadly speaking, three sources of linguistic data we can draw upon to infer facts about language." They are introspection, elicitation, and observation. Introspection is a traditional method of studying language, which relies on our own intuitive competence as the data source; elicitation is a way that is based on the intuitions of other members in the community, obtaining the data of the code or its communicative use; observation is to collect and analyze the data of actually occurring language. 
The examples in this paper mostly adopt the method of introspection in that Widdowson (1996/2000, p. 74) pointed out that "the intuitions that people have about their language have their own validity as data." $\mathrm{He}$ (ibid., p. 74) further pointed out that "intuitive, elicited, and observed data all have their own validity, but this validity depends on what kind of evidence you are looking for, on what aspects of language knowledge or behavior you are seeking to explain. If you are looking for evidence of the internal relationship between language and the mind, you are more likely to favor intuition and elicitation... The validity of different kinds of linguistic data is not absolute but relative: one kind is no more 'real' than another. It depends on what you claim the data are evidence of, and what you are trying to explain." Therefore, the examples in this paper are both reasonable and valid.

\section{Discussion}

As is discussed above, a nominal group usually consists of a headword (the Thing) and one or more modifiers. Modifiers fall into two types: Premodifiers and Qualifiers. Premodifiers precede the Thing while Qualifiers lie behind the Thing. Premodifiers may contain several fixed items: determiner, numeral and adjective and sometimes even noun, and they realize different functions in a nominal group, respectively they are, Deictic, Numerative, Epithet, and Classifier. Premodifiers serve as characterizing the Thing.

Now that Qualifiers are seldom used in Chinese, we place most emphasis on the discussion of the word sequence of Premodifiers in both languages.

\subsection{The Similarities}

\subsubsection{Modifications of the Thing}

According to Halliday and Matthiessen (2004, p. 325), "the element we are calling 'Thing' is the semantic core of the nominal group. It may be common noun, proper noun or (personal) pronoun." That is to say, no matter how many Premodifiers or Qualifiers there are, all of these items should center on the core element, the Thing. The Thing is the core of the nominal groups in both languages. The examples are set out in Table 3 :

Table 3. Examples of the modifications of the thing

\begin{tabular}{lllll}
\hline a & beautiful & Chinese & woolen & coat \\
\hline $\begin{array}{c}\text { yijian } \\
\text { 一件 }\end{array}$ & $\begin{array}{l}\text { piaoliang de } \\
\text { 漂亮的 }\end{array}$ & $\begin{array}{l}\text { zhongshi } \\
\text { 中式 }\end{array}$ & $\begin{array}{l}\text { yangmao } \\
\text { 羊毛 }\end{array}$ & $\begin{array}{l}\text { shan } \\
\text { 衫 }\end{array}$ \\
a & nice & English & pop & song \\
yishou & dongtingde & yingyu & liuxing & gequ \\
一首 & 动听的 & 流行 & 歌曲 \\
those & war-weary & US & Special & Forces \\
naxie & yanzhande & meiguo & tezhong & bing \\
那些 & 庈战的 & 美国 & 特种 & 兵 \\
Deictic & Epithet 1 & Classifier & Classifier & Thing \\
\hline
\end{tabular}

As is shown in Table 3, the word sequence in both nominal groups follows the same pattern: Deictic $\rightarrow$ Epithet $1 \rightarrow$ Classifier $\rightarrow$ Classifier $\rightarrow$ Thing. All the items preceding the Thing exert the same function as the attributes of the Thing. They all function as the modifications of the Thing. In other words, the Thing serves as the semantic core of the whole nominal group, and all the other modifiers should be endocentric to it.

\subsubsection{Similar Usages of the Diectics}

"The Deictic element indicates whether or not some specific subset of the Thing is intended; and if so, which" (Halliday \& Matthiessen 2004, p. 312). Deictic falls into two types: specific, such as the, those, his, her, whose and Joy's, etc. and non-specific, such as $a(n)$, one, no and each, etc. The Deictic precedes the Thing in both languages. The examples are listed in Table 4: 
Table 4. Similar usages of the deictics

\begin{tabular}{ll}
\hline the & book \\
\hline naben & shu \\
那本 & 书 \\
those & apples \\
naxie & pingguo \\
那些 & 苹果 \\
this & car \\
zheliang & che \\
这辆 & 车 \\
Joy's & bike \\
Qiaoyi de & zixingche \\
乔伊的 & 自行车 \\
an & egg \\
yige & jidan \\
一个 & 鸡蛋 \\
Deictic & Thing \\
\hline
\end{tabular}

It is not difficult to find that this principle is applicable to both languages, for we can say the book, those apples in English and naben shu 那本书, and naxie pingguo 那些苹果 in Chinese, but the wordings *book the, *apples those, shu naben 书那本, and pingguo naxie 苹果那些 are totally incorrect. According to Halliday and Matthiessen (2004, p. 316), "there may be a second Deictic element in the nominal group, one which adds further to the identification of the subset in question. We will refer to these as post-Deictic or Deictic2." For example, the word necessary in the sentence This is the necessary first step. "The post-Deictic identifies a subset of the class of 'thing' by referring to its fame or familiarity, its status in the text, or its similarity/dissimilarity to some other designated subset" (ibid., p. 316). Even so, they precede the Thing as well.

\subsubsection{Similar Usages of the Numeratives}

"The Numerative element indicates some numerical feature of the particular subset of the Thing: either quantity or order, either exact or inexact" (ibid., p. 317). The Numerative precedes the Thing in both languages in most cases. The examples are set out in Table 5:

Table 5. Similar usages of the numeratives

\begin{tabular}{ll}
\hline five & stars \\
\hline wuke & $\begin{array}{l}\text { xing } \\
\text { 旦颗 }\end{array}$ \\
several & guys \\
jige & jiahuo \\
几个 & 家伙 \\
a number of & passengers \\
daliangde & chengke \\
大量的 & 乘客 \\
a few & stories \\
jige & gushi \\
\hline
\end{tabular}




\begin{tabular}{ll}
\hline 几个 & 故事 \\
many & people \\
xueduode & ren \\
许多的 & $人$ \\
the first & time \\
diyi & $c i$ \\
第一 & 次 \\
Numerative & Thing \\
\hline
\end{tabular}

Strictly speaking, in most cases, the Numerative precedes the Thing. It usually serves to specify the quantity of the Thing, such as five stars (wuke xing 五颗星 in Chinese), several guys (jige jiahuo 几个家伙 in Chinese), or the order of the Thing, such as the first time (diyi ci 第一次 in Chinese). Nevertheless, there exist exceptional instances in Chinese nominal groups: sometimes the Numerative may appear behind the Thing. For example, when Jack comes into a restaurant, the waitress asks for his order. Jack casually replies, "huashengmi yipan, pijiu yiping, mifan yiwan, jiu zhexie. 花生一盘, 啤酒一瓶, 米饭一碗, 就这些。” (which means a plate of peanuts, a bottle of beer, a bowl of rice, and that's all)The analysis is set out in Table 6:

Table 6. Usages of the numeratives in Chinese nominal groups

\begin{tabular}{lll}
\hline $\begin{array}{l}\text { huashengmi } \\
\text { 花生米 }\end{array}$ & $\begin{array}{l}\text { yipan } \\
\text { 一盘 }\end{array}$ & $\sqrt{ }$ \\
\hline $\begin{array}{l}\text { yipan } \\
\text { 一盘 }\end{array}$ & $\begin{array}{l}\text { huashengmi } \\
\text { 花生米 }\end{array}$ & $\sqrt{ }$ \\
pijiu & yipping & $\sqrt{ }$ \\
啤酒 & 一瓶 & \\
yipping & pijiu & $\sqrt{ }$ \\
一瓶 & 啤酒 & \\
mifan & yiwan & $\sqrt{ }$ \\
米饭 & 一碗 & \\
yiwan & $\begin{array}{l}\text { mifan } \\
\text { 一碗 }\end{array}$ & $\sqrt{ }$ \\
\hline
\end{tabular}

As opposed to it, the English wordings are listed for contrast as well in Table 7:

Table 7. Contrastive usages of the numeratives in English nominal groups

\begin{tabular}{lll}
\hline a plate of & peanuts & $\sqrt{ }$ \\
\hline peanuts & a plate of & $\times$ \\
a bottle of & beer & $\sqrt{ }$ \\
beer & a bottle of & $\times$ \\
a bowl of & rice & $\sqrt{ }$ \\
rice & a bowl of & $\times$ \\
\hline
\end{tabular}

From the above contrast, it can be seen that the Numerative can be placed behind the Thing according to specific syntactic meanings in Chinese nominal groups while those in English cannot be so. 


\subsubsection{Similar Usages of the Epithets}

"The Epithet indicates some quality of the subset, for example old, long, blue, fast. This may be an objective property of the thing itself; or it may be an expression of the speaker's subjective attitude towards it, for example splendid, silly, fantastic" (ibid., p. 318). The former are experiential Epithets, whereas the latter, expressing the speaker's attitude, are named interpersonal Epithets. In most instances, the Epithet precedes the Thing in both languages. The examples are set out in Table 8:

Table 8. Similar usages of the epithets

\begin{tabular}{llll}
\hline$a$ & lovely & little & town \\
\hline $\begin{array}{l}\text { yige } \\
\text { 一个 }\end{array}$ & $\begin{array}{l}\text { keaide } \\
\text { 可爱的 }\end{array}$ & xiao & $\begin{array}{c}\text { zhen } \\
\text { 镇 }\end{array}$ \\
some & beautiful & red & apples \\
yixie & $\begin{array}{l}\text { piaoliangde } \\
\text { 些 }\end{array}$ & hong & pingguo \\
that & elegant & 红 & 苹果 \\
nawei & youyade & old & lady \\
那位 & 优雅的 & lao & furen \\
Deictic & Interpersonal Epithet & 老 & 妇人 \\
\hline
\end{tabular}

As is seen, the interpersonal Epithets tend to precede the experiential ones and the experiential Epithets are potentially defining, whereas interpersonal ones are not, but one thing is definite: they precede the Thing. Both in English and Chinese nominal groups, experiential Epithets help to define which particular entity we are talking about, for example, if I say a little town (yige xiaozhen 一个小镇 in Chinese), then you can tell what I am talking about is a little town but not a big town (yige dade zhenzi 一个大的镇子 in Chinese) or a lonely town (yige huangliangde zhenzi 一个荒凉的镇子 in Chinese), in that the experiential Epithet little (xiao 小 in Chinese) indicates the necessary information that helps to identify the entity. The interpersonal Epithets, on the other hand, such as some beautiful apples (yixie piaoliangde pingguo 一些漂亮的苹果 in Chinese), this is not defining, for beautiful (piaoliangde 漂亮的 in Chinese) is a totally subjective attitude towards an entity. In most cases, both languages follow this pattern, however, there are exceptional occasions in English. For example, yixiexinxianshi 一些新鲜事 in Chinese, xinxiande 新鲜的 is an Epithet, which precedes the Thing, while in English, it is transformed into something new. Obviously, new is an adjective, namely, the Epithet, lying behind the Thing, which never occurs in Chinese nominal groups, such as *yixieshixinxiande 一些事新鲜的, *yishuhuapiaoliangde 一束花漂亮的, *yigenvhaikeaide 一个女孩可爱的. Some more examples are shown in Table 9:

Table 9. Contrast of usages of the epithets

\begin{tabular}{lll}
\hline the audience & present & $\sqrt{ }$ \\
\hline $\begin{array}{l}\text { guanzhong } \\
\text { 观众 }\end{array}$ & $\begin{array}{l}\text { zaichangde } \\
\text { 在场的 }\end{array}$ & $\times$ \\
people & alive & $\sqrt{ }$ \\
ren & $\begin{array}{l}\text { huozhede } \\
\text { 活着的 }\end{array}$ & $\times$ \\
ablaze & $\sqrt{ }$ \\
the house & zhaohuode \\
房子 & 着火的 & $\times$ \\
Thing & Epithet & \\
\hline
\end{tabular}




\subsubsection{Similar Usages of the Classifiers}

"The Classifier indicates a particular subclass of the thing in question, e.g., electric trains, passenger trains, toy trains" (ibid., p. 319). Halliday and Matthiessen (2004, p. 320) said that "a sequence of Classifier + Thing may be so closely bonded that it is very like a single compound noun." This is the manifestation of the here-\&-now principle mentioned above, for the Classifier is the permanent attributive of the Thing. The principle fits in both languages: The Classifier stands closest to the Thing. The examples are as follows:

Table 10. Similar usages of the classifiers

\begin{tabular}{llll}
\hline the & nice & woolen & coat \\
\hline $\begin{array}{l}\text { najian } \\
\text { 那件 }\end{array}$ & $\begin{array}{l}\text { piaoliangde } \\
\text { 漂亮的 }\end{array}$ & $\begin{array}{l}\text { yangrong } \\
\text { 羊线 }\end{array}$ & $\begin{array}{l}\text { shan } \\
\text { 衫 }\end{array}$ \\
an & expensive & train & model \\
yige & $\begin{array}{l}\text { angguide } \\
\text { 昂贵的 }\end{array}$ & $\begin{array}{l}\text { huoche } \\
\text { 火车 }\end{array}$ & $\begin{array}{l}\text { moxing } \\
\text { 模型 }\end{array}$ \\
his & exaggerated & acting & style \\
tade & $\begin{array}{l}\text { kuazhangde } \\
\text { 夸张的 }\end{array}$ & biaoyan & fengge \\
风的 & 表演 & 格 \\
Deictic & Epithet & Classifier & Thing \\
\hline
\end{tabular}

As is shown in Table 10, both English nominal groups and Chinese nominal groups follow the same pattern without exception. The Classifiers woolen, train, and acting (yangrong 羊线, huoche 火车, and acting 表演 in Chinese) are all closely attached to the Thing.

In summary, Chinese nominal groups and English ones share some common characteristics in word sequence of the Premodifiers. By contrast, we may get a clearer understanding of the word sequence of nominal groups in both languages. Even though they share some similarities, on the other hand, they also differ from each other in many aspects.

\subsection{The Differences}

\subsubsection{Different Usages of the Diectics}

The different usages of Deictics are shown in Table 11. As is seen in Table 11, the different usages of Deictics between two languages are obvious. First, the Deictics cannot co-exist in a single nominal group in English while they can do so in Chinese. We can say tadenabenzidian 他的那本字典 in Chinese while his the dictionary is invalid in English. We can only say either his dictionary or the dictionary. What is more, the uses of Deictics in Chinese nominal groups are not only reasonable but their positions are also flexible. In other words, the positions of the Deictics are not fixed. Instead, they can be adjusted according to what the speaker aims to put emphasis on. For example,

Xiaozhangde naben zidian shi jielaide. 小张的那本字典是借来的。

Naben Xiaozhangde zidian shi jielaide. 那本小张的字典是借来的。

(which means Xiaozhang borrowed that dictionary in English)

Table 11. Different usages of the diectics

\begin{tabular}{llll}
\hline $\begin{array}{l}\text { tade } \\
\text { 他的 }\end{array}$ & $\begin{array}{l}\text { naben } \\
\text { 那本 }\end{array}$ & $\begin{array}{l}\text { zidian } \\
\text { 字典 }\end{array}$ & $\sqrt{ }$ \\
\hline his & the & dictionary & $\times$ \\
$\begin{array}{l}\text { naben } \\
\text { 那本 }\end{array}$ & $\begin{array}{l}\text { tade } \\
\text { 他的 }\end{array}$ & $\begin{array}{l}\text { zidian } \\
\text { 字典 }\end{array}$ & $\sqrt{ }$ \\
\hline
\end{tabular}




\begin{tabular}{llll}
\hline the & his & dictionary & $\times$ \\
his & & dictionary & $\sqrt{ }$ \\
the & dictionary & $\sqrt{ }$ \\
tade & naxie & $\begin{array}{l}\text { pengyou } \\
\text { 朋友 }\end{array}$ & $\sqrt{ }$ \\
她的 & 那些 & friends & $\times$ \\
her & those & pengyou & $\sqrt{ }$ \\
naxie & tade & 月月友 & \\
那些 & 她的 & friends & $\times$ \\
those & her & friends & $\sqrt{ }$ \\
those & & friends & $\sqrt{ }$ \\
her & & Thing & \\
Deictic 1 & Deictic 2 & & \\
\hline
\end{tabular}

\subsubsection{Different Usages of the Premodifiers and Qualifiers}

The different usages of Premodifiers and Qualifiers in both languages are set out in Table 12. Premodifiers are most used in Chinese nominal groups rather than Qualifiers, even though sometimes it is a clause. In other words, all the modifiers precede the Thing rather than lie behind the Thing, just as Xiaohuang zuotian maide naben zidian 小黄昨天买的那本字典 (the dictionary that Xiaozhang bought yesterday in English) in Table 12. Here one thing should be clarified: Even though clauses can also be used as Premodifiers in English nominal groups, such as $a$ do-it-yourself job, on the one hand, they are taken as informal usage that bears some colloquial or slang flavor; on the other hand, even Quirk et al. (1985, p. 1337) pointed out that "for the most part, however, sentence premodifiers have an air of the outrageous and improvised." Consequently, we firmly argue that sentences as Premodifiers in English nominal groups are some kind of variants that should not be included in Premodifiers in a real sense.

Table 12. Different usages of the premodifiers and qualifiers

\begin{tabular}{|c|c|c|c|}
\hline $\begin{array}{l}\text { Xiaohuang zuotian maide naben } \\
\text { 小黄昨天买的那本 }\end{array}$ & $\begin{array}{l}\text { zidian } \\
\text { 字典 }\end{array}$ & O & $\sqrt{ }$ \\
\hline Xiaohuang yesterday bought the & dictionary & $\mathrm{O}$ & $x$ \\
\hline $\begin{array}{l}\text { Naben Xiaohuang zuotian maide } \\
\text { 那本小黄昨天买的 }\end{array}$ & $\begin{array}{l}\text { zidian } \\
\text { 字典 }\end{array}$ & $\mathrm{O}$ & $\sqrt{ }$ \\
\hline the Xiaohuang yesterday bought & dictionary & $\mathrm{O}$ & $x$ \\
\hline $\begin{array}{l}\text { Zuotian Xiaohuang maide naben } \\
\text { 昨天小黄买的那本 }\end{array}$ & $\begin{array}{l}\text { zidian } \\
\text { 字典 }\end{array}$ & $\mathrm{O}$ & $\sqrt{ }$ \\
\hline yesterday Xiaohuang bought the & dictionary & O & $x$ \\
\hline Premodifiers & Thing & Qualifiers & \\
\hline O & the dictionary & that Xiaohuang bought yesterday & $\sqrt{ }$ \\
\hline 0 & the dictionary & that Xiaohuang yesterday bought & $\sqrt{ }$ \\
\hline
\end{tabular}

On the contrary, either Premodifiers or Qualifiers are used in English nominal groups. Qualifiers are the most commonly used techniques in English nominal groups, which generally are realized by groups, phrases and clauses, whereas they are seldom used in Chinese nominal groups. In this sense, the use of modifiers in Chinese nominal groups is not as variable and flexible as those in English. Another contrast can better exemplify this 
point. The nominal group in Chinese yiwei chuanzhe baiseyifu de nvshi 一位穿着白色衣服的女士 can be transformed into three different expressions in English: (i) A lady who is dressed in white; (ii) A lady dressed in white; (iii) A lady in white. As a result, in this respect, the Modifiers in Chinese nominal groups are not as productive as those in English.

\subsubsection{Different Sequences of the Deictics and Epithets}

The sequence of the Deictics and Epithets is the obvious difference in both languages as well. The examples are set out in Table 13:

Table 13. Different sequences of the deictics and epithets

\begin{tabular}{lllll}
\hline $\begin{array}{l}\text { yiwei } \\
\text { 一位 }\end{array}$ & $\begin{array}{l}\text { feichangshuaiqide } \\
\text { 非常帅气的 }\end{array}$ & $\begin{array}{l}\text { nianqing } \\
\text { 年轻 }\end{array}$ & $\begin{array}{c}\text { nanzi } \\
\text { 男子 }\end{array}$ & V \\
\hline$a$ & veryhandsome & young & man & $\sqrt{ }$ \\
Deictic & Epithet & Classifier & Thing & \\
$\begin{array}{l}\text { feichangshuaiqide } \\
\text { 非常帅气的 }\end{array}$ & yiwei & nianqing & nanzi & $\sqrt{ }$ \\
veryhandsome & 一位 & 年轻 & 男子 & \\
Epithet & $a$ & young & man & $\times$ \\
\hline
\end{tabular}

In English nominal groups, as we discovered, the Deictics must precede the Epithets, which is also conformed to the here-and-now principle. The progression in the nominal group starts from the kind of element that has the greatest specifying potential to that which has the least. Obviously, the Deictics bear more specifying potential than Epithets. In this sense, this is the common principle of ordering that we have already recognized in the nominal groups. Here are more examples about it.

$$
\begin{aligned}
& \text { (i) a very beautiful dress } \\
& \text { *very beautiful a dress } \\
& \text { (ii) a wonderful trip } \\
& \text { *wonderful a trip } \\
& \text { (iii) a very tall building } \\
& \text { *very tall a building }
\end{aligned}
$$

As we can see, the positions of the Deictics and Epithets in English nominal groups are highly restricted and they cannot be exchanged randomly. However, the conversions of Deictics and Epithets are very common in Chinese nominal groups. Their positions are not that strict, which are quite flexible. For example,

$$
\begin{aligned}
& \text { (i) yijian hen piaoliangde qunzi 一件很漂亮的裙子 } \\
& \text { hen piaoliangde yijian qunzi 很漂亮的一件裙子 } \\
& \text { (ii) yici meimiaode lvxing 一次美妙的旅行 } \\
& \text { meimiaode yici lvxing 美妙的一次旅行 } \\
& \text { (iii) yidong feichanggaode jianzhuwu 一栋非常高的建筑物 } \\
& \text { feichanggaode yidong jianzhuwu 非常高的一栋建筑物 }
\end{aligned}
$$

And these expressions are not only valid in Chinese, but they are also widely used in daily communications. In this sense, the use of Premodifiers in Chinese nominal groups, especially the word sequence of the Premodifiers, are more variable and flexible than those in English.

\subsubsection{Different Usages of the Here-\&-Now Principle}

The here-and-now principle in English nominal groups sometimes is not applicable to Chinese nominal groups, especially when there are several Epithets characterizing the Thing. Here are the examples in Table 14: 
Table 14. Different usages of the here-\&-now principle

\begin{tabular}{|c|c|c|c|c|c|c|c|c|c|c|}
\hline$a$ & pretty & little & square & old & black & Japanese & wooden & writing & desk & $\sqrt{ }$ \\
\hline yige & piaoliangde & xiaode & fangxingde & jiude & heisede & ribenshide & muzhide & xiezi & zhuo & $x$ \\
\hline 一个 & 漂亮的 & 小的 & 方形的 & 旧的 & 黑色的 & 日本式的 & 木质的 & 写字 & 桌 & \\
\hline Deictic & Epithet 1 & Epithet 2 & Epithet 3 & Epithet 4 & Epithet 5 & Epithet 6 & Epithet 7 & Classifier & Thing & \\
\hline yige & jiude & piaoliangde & heisede & ribenshide & fangxing & muzhi & xiao & xiezi & zhuo & $\sqrt{ }$ \\
\hline 一个 & 旧的 & 漂亮的 & 黑色的 & 日本式的 & 方形 & 木质 & 小 & 写字 & 桌 & \\
\hline
\end{tabular}

a pretty square old black Japanese wooden writing desk is beautifully conformed to the here-and-now principle. $a$ is the Deictic, apparently, and lies at the head of the nominal group; pretty is an interpersonal Epithet, as is discussed above, which should precede the other experiential Epithets; little $\rightarrow$ square $\rightarrow$ old $\rightarrow$ black $\rightarrow$ Japanese $\rightarrow$ wooden, all these items function as experiential Epithets, which are ordered from the temporal specification little to the permanent attribute wooden; writing lies closet to the core, serving as the Classifier and desk is the Thing. However, following the same word sequence in Chinese nominal group, we will find it very rigid and clumsy to use: yige piaoliangde xiaode fangxingde jiude heisede ribenshide muzhide xiezizhuo 一个漂 亮的小的方形的黑色的日本式的木质的写字桌. The wording reads clumsy and redundant. Obviously, the wording does not accord with the Chinese logic. On the contrary, yige jiude piaoliangde heisede ribenshide fangxing muzhi xiaoxiezi zhuo 一个旧的漂亮的黑色的日本式的方形木质小写字桌 is much clearer and more coherent. Here is another example:

Table 15. Another example of different usages of the here-and-now principle

\begin{tabular}{|c|c|c|c|c|c|c|c|}
\hline two & big & round & new & Chinese & wooden & tables & $\sqrt{ }$ \\
\hline $\begin{array}{l}\text { liangzhang } \\
\text { 两张 }\end{array}$ & $\begin{array}{l}\text { dade } \\
\text { 大的 }\end{array}$ & $\begin{array}{l}\text { yuande } \\
\text { 圆的 }\end{array}$ & $\begin{array}{l}\text { xinde } \\
\text { 新的 }\end{array}$ & $\begin{array}{l}\text { zhongguoshide } \\
\text { 中国式的 }\end{array}$ & $\begin{array}{l}\text { muzhide } \\
\text { 木质的 }\end{array}$ & $\begin{array}{l}\text { zhuo } \\
\text { 桌 }\end{array}$ & $x$ \\
\hline Deictic & Epithet 1 & Epithet 2 & Epithet 3 & Epithet 4 & Classifier & Thing & \\
\hline $\begin{array}{l}\text { liangzhang } \\
\text { 两张 }\end{array}$ & $\begin{array}{l}\text { xinde } \\
\text { 新的 }\end{array}$ & $\begin{array}{l}\text { zhongguoshide } \\
\text { 中国式的 }\end{array}$ & $\begin{array}{l}\text { muzhi } \\
\text { 木质 }\end{array}$ & $\begin{array}{l}d a \\
\text { 大 }\end{array}$ & $\begin{array}{l}\text { yuan } \\
\text { 圆 }\end{array}$ & $\begin{array}{l}\text { zhuo } \\
\text { 桌 }\end{array}$ & $\sqrt{ }$ \\
\hline
\end{tabular}

Apparently, the Chinese wording liangzhangxindezhongguoshidemuzhi da yuan zhuo 两张新的中国式木质大 圆桌 is not corresponding with Halliday's here-and-now principle. The reasons can be manifold. Just as Quirk et al. (1985, p. 1338) said that "although there is, theoretically, no grammatical upper limit to the number of premodifiers, it is unusual to find more than three or four. Premodification is an area of English grammar where there is considerable variation among the varieties of the language. To a large extent, such variation, as well as the existence of an upper limit, can be given a psycholinguistic explanation." Due to the space limitations, we will not cover them in depth.

\section{Conclusion}

This paper attempts to make a contrastive study of the word sequence in nominal groups in English and Chinese, adopting a systemic functional approach. First, we had a review of the studies on the nominal groups conducted from different theories, from which this paper selects Halliday's SFG as its theoretical framework, in that few studies are carried out in this perspective to make a contrastive study of the nominal groups in both languages. This also can be considered as the originality of the paper. Then this paper briefly introduces the theoretical framework applied in the analysis in order to make the illustration more comprehensive.

Through the discussion, the findings can be summarized into the following aspects: first, in most cases, both Chinese nominal groups and English nominal groups share similarities in their components and organization structures. For example, the Thing is the core; almost all the Deictics, epithets and Numeratives precede the Thing; the Classifier stands closet to the Thing.

However, they can also differ from each other in many other aspects. First, the Deictics cannot co-exist in a single nominal group in English while they can do so in Chinese; second, the positions of the items in 
Premodifiers in Chinese nominal groups are much more variable and flexible than those in English nominal groups. Instead, the English nominal groups utilize the Qualifiers to make up their deficiencies; third, the conversions of Deictics and Epithets are very common in Chinese nominal groups while they are forbidden in English; at last, some of the Chinese nominal groups violate Halliday's here-and-now principle for certain reasons, which needs further discussion in our following studies.

\section{Acknowledgments}

This research is financially supported by the national project: A Contrastive Study of the English and Chinese Nominal Groups: A Systemic Functional Approach (12BYY007). Guichao Zhang is the first author, and Manliang $\mathrm{Li}$ is the corresponding author.

\section{References}

Bloor, T., \& Bloor, M. (1995/2001). The Functional Analysis of English: A Hallidayan Approach. London: Arnold. / Beijing: Foreign Language Teaching and Research Press.

Fawcett, R. P. (2008). Invitation to Systemic Functional Linguistics through the Cardiff Grammar: An extension and simplification of Halliday's Systemic Functional Grammar (3rd ed.). London: Equinox.

Halliday, M. A. K. (1994/2000). An Introduction to Functional Grammar (2nd ed.). London: Arnold. / Beijing: Foreign Language Teaching and Research Press.

Halliday, M. A. K., \& Matthiessen, C. M. I. M. (2004). An Introduction to Functional Grammar (3rd ed.). London: Arnold.

He, W., \& Hong, N. Z. (2014). "De” Zai Hanyu Mingcicizuzhong de Gongneng Yanjiu (A Functional Study of de within Chinese Nominal Groups). Jiefangjun Waiguoyu Xueyuan Xuebao (Journal of PLA University of Foreign Languages), (5), 82-90.

Li, M. L. (2009). Xiniyufa he Jiadifuyufa dui Yingyu Mingcicizu Yanjiu de Bijiao (Comparison of Descriptions of English Nominal Groups between the Sydney Grammar and the Cardiff Grammar). Beijing Keji Daxue Xuebao (Shehui Kexue Ban) (Journal of University of Science and Technology Beijing (Social Sciences Edition)), (1), 112-119.

Li, M. L. (2013). A Systemic Functional Study of the English Nominal Group. Hohhot: Inner Mongolia University Press.

Li, M. L., \& Du, H. Y. (2012). Jieciduanyu Zuowei Houzhixiushiyu de Yingyu Mingcicizu Gongnengjufa Fenxi (A Systemic Functional Analysis of the English Nominal Groupwith the Prepositional Phrase as the Qualifier). Beijing Keji Daxue Xuebao (Shehui Kexue Ban) (Journal of University of Science and Technology Beijing (Social Sciences Edition)), (2), 25-30.

Peng, X. W. (2009). Xiandaihanyu Mingcicizuzhong de Zhibie Chengfenxitong ji Yuxu (Deictic Elements and Their Orders in Mandarin Nominal Group). Beijing Shifan Daxue Xuebao (Shehui Kexue Ban) (Journal of Beijing Normal University (Social Science)), (5), 54-61.

Quirk, R., Greenbaum, S., Leech, G., \& Svartvik, J. (1985). A Comprehensive Grammar of the English Language. London: Longman.

Thompson, G. (1996/2000). Introducing Functional Grammar (1st ed.). London: Arnold. / Beijing: Foreign Language Teaching and Research Press.

Widdowson, H. G. (1996/2000). Linguistics. Oxford: Oxford University Press. / Shanghai: Shanghai Foreign Language Education Press.

Zhang, J. Y., \& Kong, A. A. (2010). Yingyu Mingcicizu Zhongxinci Tanxi (Exploration of Head in Nominal Groups in English) Beijing Keji Daxue Xuebao (Shehui Kexue Ban) (Journal of University of Science and Technology Beijing (Social Sciences Edition)), (1), 89-95.

\section{Copyrights}

Copyright for this article is retained by the author, with first publication rights granted to the journal.

This is an open-access article distributed under the terms and conditions of the Creative Commons Attribution license (http://creativecommons.org/licenses/by/4.0/). 